\title{
Exercise training acts as a therapeutic strategy for reduction of the pathogenic phenotypes for Alzheimer's disease in an NSE/APPsw-transgenic model
}

\author{
HYUN SEOB UM ${ }^{1}$, EUN BUM KANG ${ }^{1}$, YEA HYUN LEEM ${ }^{1}$, IN HO CHO ${ }^{1}$, CHUN HO YANG $^{2}$, \\ KAB RYONG CHAE ${ }^{3}$, DAE YOUN HWANG ${ }^{4}$ and JOON YONG CHO ${ }^{1}$
}

\author{
${ }^{1}$ Exercise Biochemistry Laboratory, Korea National Sport University, Seoul 138-763; ${ }^{2}$ Department of \\ Aviation and Marine Sports, University of Han-Seo, Seosansi 306-706; ${ }^{3}$ Laboratory Animal Resources \\ Team, National Institute of Toxicological Research, Korea FDA, Seoul 122-704; ${ }^{4}$ School of Applied Life \\ Science, College of Natural Resources \& Life Science, Pusan National University, Miryang 627-706, Korea
}

Received May 12, 2008; Accepted June 20, 2008

DOI: 10.3892/ijmm_00000052

\begin{abstract}
Alzheimer's disease (AD) is a progressive neurodegenerative disease for which there are few therapeutic regimens that influence the underlying pathogenic phenotypes. However, of the currently available therapies, exercise training is considered to be one of the best candidates for amelioration of the pathological phenotypes of AD. Therefore, we directly investigated exercise training to determine whether it was able to ameliorate the molecular pathogenic phenotypes in the brain using a neuron-specific enolase (NSE)/Swedish mutation of amyloid precursor protein (APPsw) transgenic ( $\mathrm{Tg}$ ) mice as a novel AD model. To accomplish this, Non-Tg and NSE/ APPsw Tg mice were subjected to exercise on a treadmill for 16 weeks, after which their brains were evaluated to determine whether any changes in the pathological phenotyperelated factors had occurred. The results indicated (i) that amyloid $B-42(A ß-42)$ peptides were significantly decreased in the NSE/APPsw Tg mice following exercise training; (ii) that exercise training inhibited the apoptotic biochemical cascades, including cytochrome c, caspase-9, caspase- 3 and Bax; (iii) that the glucose transporter-1 (GLUT-1) and brainderived neurotrophic factor (BDNF) proteins induced by exercise training protected the neurons from injury by inducing
\end{abstract}

Correspondence to: Professor Joon Yong Cho, Exercise Biochemistry Lab, Korea National Sport University, 88-15 Oryun-dong, Songpa-gu, Seoul 138-763, S. Korea

Professor Dae Youn Hwang, School of Applied Life Science, College of Natural Resources \& Life Science, Pusan National University, 50 Cheonghak-ri, Samnangjin-eup, Miryang-si, Gyeongsangnam-do 627-706, Korea

E-mail: chojy86@knsu.ac.kr,dyhwang@pusan.ac.kr

Key words: Alzheimer's disease, exercise training, glucose transporter, heat-shock protein, supeoroxide dismutase-1 the concomitant expression of genes that encode proteins such as superoxide dismutase-1 (SOD-1), catalase and Bcl-2, which suppress oxidative stress and excitotoxic injury; (iv) that heat-shock protein-70 (HSP-70) and glucose-regulated protein-78 (GRP-78) were significantly increased in the exercise (EXE) group when compared to the sedentary (SED) group, and that these proteins may benefit the brain by making it more resistant to stress-induced neuron cell damage; (v) and that exercise training contributed to the restoration of normal levels of serum total cholesterol, insulin and glucose. Taken together, these results suggest that exercise training represents a practical therapeutic strategy for human subjects suffering from AD. Moreover, this training has the potential for use in new therapeutic strategies for the treatment of other chronic disease including diabetes, cardiovascular and Parkinson's disease.

\section{Introduction}

Alzheimer's disease (AD) is a neurodegenerative disorder characterized by the progressive loss of memory and cognitive functions that is frequently characterized by pathogenic alterations $(1,2)$. Such alterations of pathogenic phenotypes are considered to be clues to the cause of AD, especially alterations in various fields of neuronal cell metabolism such as the activation of microglia cells, the oxidation of lipids, the induction of reactive oxygen species, the progression of neurotic injury by $A \beta$, the disruption of neuronal metabolic homeostasis and neuronal cell death (3-7). Furthermore, AD has been found to be closely related to the mechanism of cell growth and death, which involves the up-regulation of caspasedependent neuronal apoptosis $(8,9)$ and the down-regulation of growth factors $(10,11)$. In addition, the pathogenic phenotypes of $\mathrm{AD}$ are tightly associated with the phenotype change involved in several chronic diseases. This is especially true in the case of phenotypes associated with diabetes, such as the dysfunction of pancreatic $\beta$ cells, which is also observed in $\mathrm{AD}$ patients. These phenotypes are involved in changes in the glucose transporters $(12,13)$, heat-shock proteins (14) and 
the concentration of cholesterol and insulin (15-17). Taken together, the findings of these studies suggest that therapeutic strategies for the treatment of human chronic diseases can be simultaneously applied to the treatment of changes in the pathogenic phenotypes of AD.

AD patients have been shown to exhibit several symptoms, including weight loss, general weakness, fatigue and decreased food intake coupled with physical inactivity $(18,19)$. Furthermore, the results of several epidemiological studies have shown that the transition from a sedentary to an active lifestyle may be sufficient to enhance cognitive abilities that can delay the onset of dementia in humans and mice (20-23).

The treatment of AD patients has traditionally focused on pharmacotherapy and dietetic therapy. However, recently various exercises have been included in AD treatment plans. The results of previous studies have suggested that exercise may be beneficial to $\mathrm{AD}$ sufferers through multiple pathways by inducing improved learning, increased synaptic plasticity, cerebrovascular function and increased production of growth factors, as well as by reducing the formation of amyloid $B-42$ (Aß-42) (24-27). However, several studies regarding the correlation of exercise training and $\mathrm{AD}$ have reported inconsistent results. For example, Wilson et al reported that exercise or physical activity for several hours a week was not associated with the risk of development of AD in small populations (28). Due to the controversy regarding the potential benefits of exercise training for $\mathrm{AD}$ patients, it is necessary to determine whether exercise training induced beneficial effects for the pathogenic phenotypes of AD using a novel animal model that expressed human-like phenotypes.

Therefore, in this study, we investigated exercise training to determine whether it could ameliorate the molecular pathogenic phenotypes of $\mathrm{AD}$ using a novel $\mathrm{AD}$ model that expressed the human APPsw gene. The results of this study indicated that exercise training induced a reduction of $A ß-42$ and inhibition of apoptotic biochemical cascades in the brains of $\mathrm{Tg}$ mice. In addition, glucose transporter-1 (GLUT-1) and the brain-derived neurotrophic factor (BDNF) protein, which are related to the protection of neurons, were significantly increased in the exercise (EXE) group when compared to the sedentary (SED) group. Taken together, these results suggest that exercise training can be applied as a novel therapeutic method for the treatment of $\mathrm{AD}$.

\section{Materials and methods}

Transgenic mice. All animal experimental procedures used in this study were approved by the Institutional Animal Care and Use Committee at Korea National Sport University and Korea FDA. NSE/APPsw Tg mice expressing the human APPsw gene under control of the neuron-specific enolase promoter (Fig. 1A) were used for this study. These mice showed AD phenotypes, including behavioral dysfunction, Aß-42 deposition and apoptosis activation at 12-13 months of age (29). The Non-Tg and Tg mice were obtained from the Department of Laboratory Animal Resources at the National Institute of Toxicological Research, Korea FDA. The mice were handled in an accredited Korea FDA animal facility according to the AAALAC International Animal Care Policies (Accredited Unit-Korea Food and Drug Administration: Unit
Number-000996). Mice were maintained under a 12:12-h dark-light cycle at $22 \pm 2{ }^{\circ} \mathrm{C}$ and $50 \%$ relative humidity, and were provided with a standard chow diet (Purina Mills Inc.) and water ad libitum.

Experimental design and treadmill exercise training. Thirteenmonth old NSE/APPsw transgenic mice (Tg mice, $\mathrm{n}=10$ ) and Non-transgenic mice (Non-Tg mice, $n=10$ ) were assigned to one of the following groups: sedentary Non-Tg mice (SED Non-Tg, $\mathrm{n}=5$ ), exercise-trained Non-Tg mice (EXE Non-Tg, $\mathrm{n}=5$ ), sedentary NSE/APPsw Tg mice (SED Tg, $\mathrm{n}=5$ ) or exercise-trained NSE/APPsw Tg mice (EXE Tg, n=5). Prior to the treadmill exercise, the mice were allowed a 1-week familiarization period to adapt to their new environment. During this period, the mice in the EXE groups were subjected to running for $10 \mathrm{~min} /$ day at a speed of $11 \mathrm{~m} / \mathrm{min}$ on a treadmill (Rodent Treadmill, Daemyung Scientific Co., Ltd., Korea). After this period, animals in the EXE Non-Tg and Tg group were subjected to running for $60 \mathrm{~min}$ a day at $22 \mathrm{~cm} / \mathrm{sec}$ and $0 \%$ grade for 5 days/week for 16 weeks, as described by Cho et al (20). However, mice in the SED group were not subjected to any exercise.

PCR analysis. To harvest total RNA, each tissue was frozen with liquid nitrogen, chopped with scissors and homogenized in RNAzol B solution (Tet-Test Inc. CS104). The isolated RNA was then quantified by UV spectroscopy. To examine the expression of the transgenes, RT-PCR was performed by annealing $500 \mathrm{ng}$ of oligo-dT primer [Gibco BRL (18418-012)] to $5 \mu \mathrm{g}$ of total RNA from each tissue sample at $70^{\circ} \mathrm{C}$ for $10 \mathrm{~min}$ in order to synthesize cDNA molecules. In addition, complementary DNA that served as a template for further amplification was synthesized by addiing dATP, dCTP, dGTP, dTTP and 200 units of reverse transcriptase. Then, 10 pmol of the sense and antisense primers were added. The reaction mixtures were amplified using a Perkin-Elmer thermal cycler to subject the samples to 28 cycles of $30 \mathrm{sec}$ at $94^{\circ} \mathrm{C}, 30 \mathrm{sec}$ at $62^{\circ} \mathrm{C}$, and $45 \mathrm{sec}$ at $72^{\circ} \mathrm{C}$. For the detection and amplification of the APP mRNA transcripts, the APP-specific sense and antisense primers used in this study were: 5 '-CGTCG ACTAT GGTGG TATGG CTGA-3' and 5'-TCGAG GACTG CAGAC TCAG-3', respectively. In each case, minus-RT controls were included to distinguish between DNA and RNA products. RT-PCR was also conducted using primers specific to $\beta$-actin to ensure the integrity of the RNA. The sequence of the $ß$-actin sense primer was 5'-TGGAA TCCTG TGGCA TCCAT GAAAC-3' and that of the anti-sense primer was 5'-TAAAA CGCAG CTCAG TAACA GTCCG-3'. These primers led to the amplification of a 640-bp segment of the APP DNA sequence. The experiment was repeated three times, and the relative difference in the RNA quantity was determined based on the results of three replicate experiments.

Western blot analysis. Western blot analyses were conducted as previously described (30). Briefly, proteins (40 $\mu \mathrm{g} /$ lane) were separated by electrophoresis in a $10 \%$ polyacrylamide gel for $3 \mathrm{~h}$, and then transferred to a nitrocellulose membrane (Immuno-Blot, PVDF membrane, Bio-Rad, CA, USA) for $2 \mathrm{~h}$ at a constant 40 volts. Each membrane was then separately incubated overnight at $4{ }^{\circ} \mathrm{C}$ with the primary antibody; anti- 
A

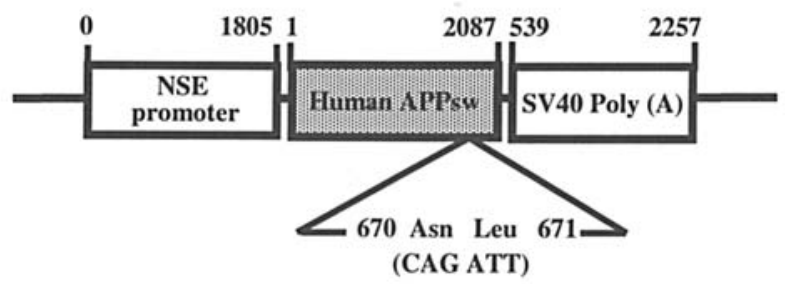

B

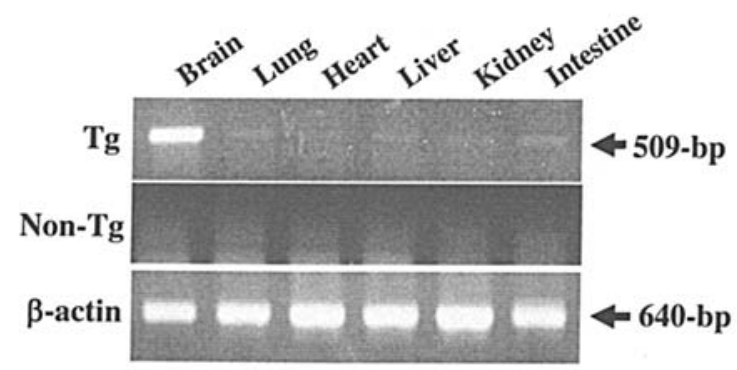

C

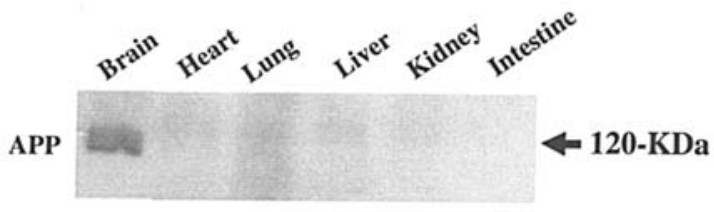

Figure 1. Construction of $p N S E / A P P s w$ and tissue-specific expression of the transgene. (A) Construction of $p N S E / P S 2 m$ plasmid. $p N S E / A P P S w$ contained the encoding APPsw that was placed under the control of the NSE gene promoter. (B) Tissue-specific expression on the hAPP transcript level. The B-actin signal served as a control, and its transcript (640-bp) is shown to indicate RNA loading. (C) APP protein level in the various tissues of Tg mice. A thick band was actually two bands in $540 \mu \mathrm{g}$ of protein. Anti-APP antibody was used for the detection of APP expression.

cytochrome c (Santa Cruz Biotechnology, sc-8385, Santa Cruz, CA, USA); anti-SOD1 (Santa Cruz Biotechnology, sc-11407, Santa Cruz); anti-HSP-70 (Santa Cruz Biotechnology, sc-24, Santa Cruz); anti-catalase (Santa Cruz Biotechnology, sc-33781, Santa Cruz); anti-BDNF (Santa Cruz Biotechnology, sc-546, Santa Cruz); anti-GLUT-1 (Santa Cruz Biotechnology, sc-7903, Santa Cruz); anti-Bcl2 (Sigma, C9804, MO, USA); anti-Bax (Sigma, B8429); anticaspase-3 (Sigma, C8487); anti-caspase-9 (Abcam, ab28131, MA, USA) and anti-Aß-42 (Chemicon, MAB1561, MA, USA). The membranes were washed with washing buffer, after which they were incubated with secondary antibodies and horseradish peroxidase (HRP)-conjugated goat anti-rabbit (ZYMED Lab, 65-6120, Carlsbad, CA, USA) for BDNF, SOD-1 and caspase-3 (1:3000) and HRP-conjugated goat anti-mouse (Santa Cruz Biotechnology, sc-2005, Santa Cruz) for amyloid B, Bax, Bcl-2, caspase-9 and HSP-70 (1:3000) and HRP-conjugated goat anti-goat (ZYMED Lab, 81-1620, Carlsbad) for cytochrome c and SOD-1 (1:3000). Membrane blots were developed using a Western blot analysis system (Santa Cruz, Biotechnology, Santa Cruz) following the manufacturer's instructions. The density of the developed bands was determined by scanning with a ChemiDoc XRS system (Bio-Rad, Hercules).
Biochemical analysis. After the exercise training on the final day, the mice were fasted for $24 \mathrm{~h}$, after which whole blood was collected from their abdominal vein. Serum was obtained by centrifuging the blood $\left(15,000 \mathrm{rpm}, 4^{\circ} \mathrm{C}, 10 \mathrm{~min}\right)$, followed by incubation for $30 \mathrm{~min}$ at room temperature. The serum was then stored at $-80^{\circ} \mathrm{C}$ until analysis. Serum biochemical components, total cholesterol (cholesterol reagent kit, Bayer, Pittsburgh, USA) and glucose (glucose hexokinase kit, Bayer), were assayed using the appropriate kit and following standard methods.

Insulin by ELISA. The level of insulin in the serum obtained from NSE/APPsw Tg and Non-Tg mice was detected using the ultra-sensitive assay procedure and reagents in the Insulin ELISA kit (Mercodia; Cat. 10-1137-01, Sweden). Briefly, the sera and standards were incubated in a plate shaker at 100$150 \mathrm{rpm}$ at room temperature for $2 \mathrm{~h}$ on antibody-coated plates. The wells were washed six times using an automatic plate washer (Hoefer, PV100, USA), after which HRP conjugate was added to each of the wells. The plates were incubated in a shaker for $30 \mathrm{~min}$ at room temperature. The reaction was terminated by the addition of $50 \mu \mathrm{l}$ of stop solution $(0.5 \mathrm{M}$ $\mathrm{H}_{2} \mathrm{SO}_{4}$ ), after which the plates were analyzed by evaluating the absorbance at $450 \mathrm{~nm}$ using a Molecular Devices $\mathrm{V}_{\max }$ Plate reader (Sunnyvale, CA, USA).

Water maze tests. The mice were subjected to water maze tests following previously described procedures $(29,31)$. Briefly, the tests were performed using the SMART-CS (Panlab, Barcelona, Spain) program, which was placed in an experimental room with a window, air-conditioning and tables. This experiment was conducted in a plastic circular pool with a diameter of $1.5 \mathrm{~m}$ and filled with water maintained at $20-22^{\circ} \mathrm{C}$. The visual field of the water was obstructed by the addition of powdered milk. Mice were pre-trained by allowing them to swim to a round platform (diameter $12 \mathrm{~cm}$ ) submerged $1 \mathrm{~cm}$ beneath the surface. The escape latencies, escape distances, swimming speeds and swimming patterns of the mice were monitored using the SMART-LD computer program, which was connected to a camera mounted to the ceiling directly above the pool. Prior to the experiment, a 60 sec habituation trial was performed to verify that the mice could swim. The mice were given five training trials in which their ability to find the hidden platform was measured for a maximum of $60 \mathrm{sec}$. If the mice failed to find the platform within the maximum time, they were physically placed on it. The training schedule consisted of two trials per day, over 5 test days, and each trial was assessed by the ability of the mouse to reach the platform within $60 \mathrm{sec}$. The second trial was conducted at least $5 \mathrm{~min}$ after the first one. However, the two trials were started from identical locations and the platform location was kept constant during the training period. After each trial, the mice were allowed to remain on the platform for $30 \mathrm{sec}$. On the sixth day, the mice were subjected to three probe trials, in which they swam for $60 \mathrm{sec}$ with no platform in the pool. In this test, each of the two training and three actual trials were initially started from the right side of the water pool, and then from the opposite side for the second trial. The patterns of searching, the number of times the mice swam to the former location of the platform (escape latency), 

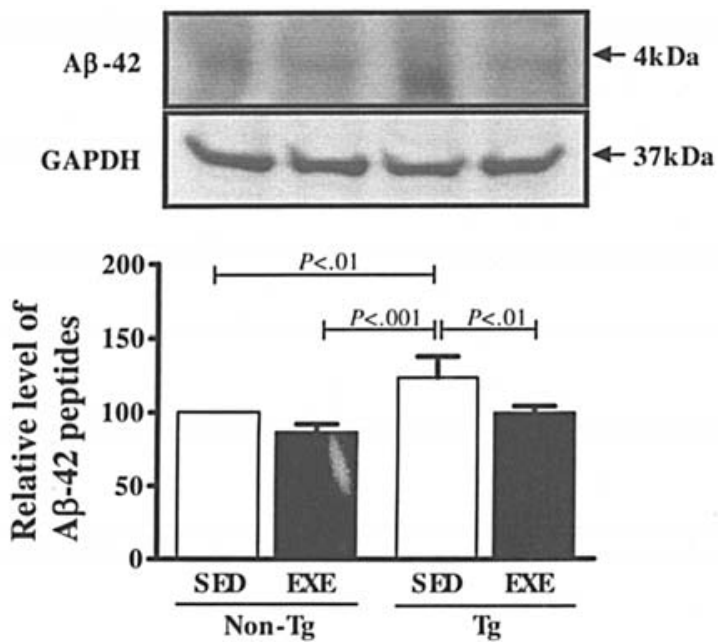

Figure 2. Changes on Aß-42 deposition in the brain of APPsw Tg mice after 16 weeks of exercise training. Levels of $A \beta-42$ in the brain were analyzed by Western blot analysis. Briefly, the brain extracts were transferred to membranes and then incubated with antibodies for Aß-42 and GAPDH. The specific activity was then detected using a Chemiluminescence Reagent Plus kit (ECL, Pharmacia). Five mice from the Non-Tg and Tg subgroups were assayed in triplicate by Western blot analysis. The values shown are the mean $\pm \mathrm{SD}$

the distances the mice swam (escape distance) and the swimming speeds (velocity) to the precise former location were recorded. All trials were recorded and stored on videotape for subsequent analysis.

Statistical analysis. The data were analyzed using SPSS (version 10.0, SPSS Inc., Chicago, IL, USA). The values were expressed as the means \pm SD. Two-way analysis of variance (group x condition) was used by Fisher's LSD post hoc test to compare the primary effects among the groups. Differences were considered statistically significant at $\mathrm{p}<0.05$.

\section{Results}

Expression of the NSE/APPSw fusion gene in the brain of transgenic mice. To evaluate the expression of the NSE/ APPsw fusion gene, transcripts and the protein levels of APPsw were examined by RT-PCR and Western blot analysis, respectively. The highest level of hAPP transcripts (509-bp) was observed in the brain of transgenic mice, whereas hAPP was not expressed in any tissues obtained from non-transgenic mice (Fig. 1B). In addition, Western blot analysis of the APP protein obtained from the brain of transgenic mice revealed the presence of a relatively high level of expression in the brain (Fig. 1B). Taken together, these results suggest that the NSE/APPsw Tg mice used in this study successfully expressed the APP protein in the brain of $\mathrm{Tg}$ mice.

Exercise training reduces A $\beta-42$ deposition in NSE/APPSwtransgenic mice. The results of previous studies demonstrated that NSE/APPsw Tg mice exhibit behavioral deficits at 13 months of age, and that these deficits are accompanied by increasing levels of Aß-42 (29). Therefore, this study initially evaluated exercise training to determine whether it affected the deposition of Aß-42 in Tg mice. To accomplish this, $\mathrm{Tg}$ mice that were 13 months old were subjected to treadmill exercise training for 16 weeks, after which the Aß-42 levels were measured in the brain extracts of $\mathrm{Tg}$ and Non-Tg mice by Western blot analysis. NSE/APPsw Tg mice that were in the sedentary condition had a higher level of $A ß-42$ than Non-Tg mice. However, these levels were significantly
A

(a)

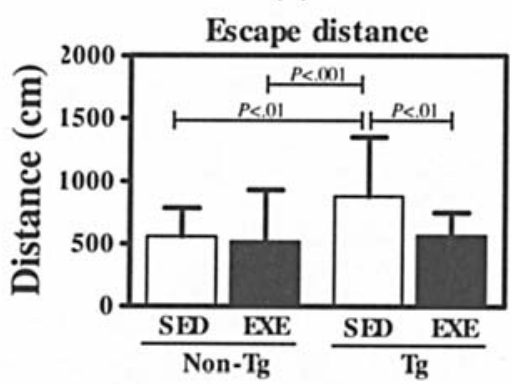

B

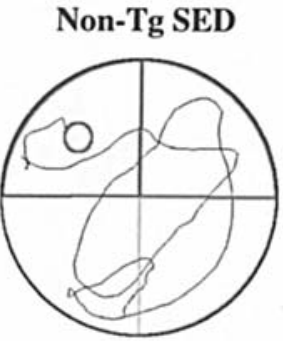

(b)

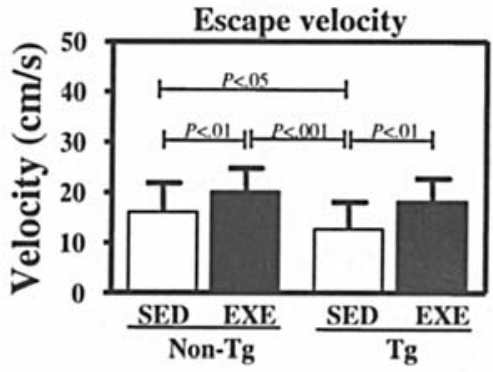

Tg SED

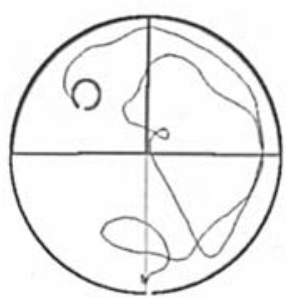

(c)

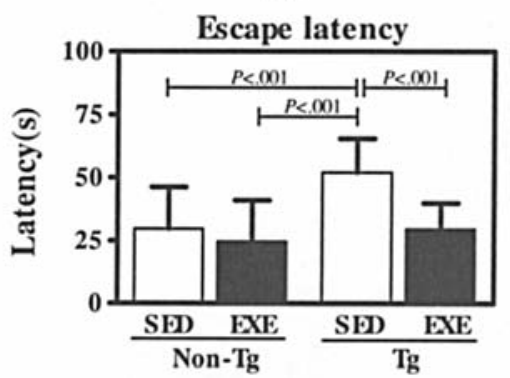

Tg EXE
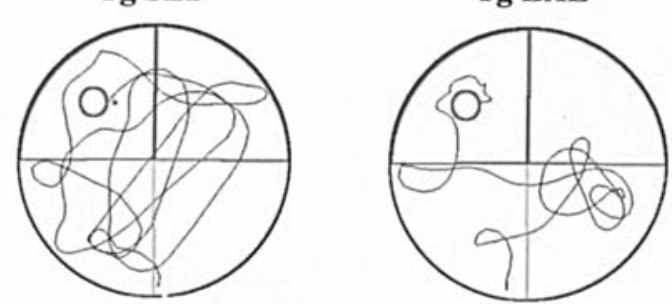

Figure 3. Water maze tests. Data (A) and patterns (B) of the escape latency, escape distance and swimming velocity of mice searching for the former platform location in the water maze. APPsw Tg mice showed a significantly different trend toward escape distance (a), velocity (b) and latency (c) upon exercise training. In addition, the swimming patterns of the EXE and SED groups were significantly different when they were crossing the former location of the platform. The mean $\pm \mathrm{SD}$ of three trials in the water maze for five mice in each of the Non- $\mathrm{Tg}$ and $\mathrm{Tg}$ mice subgroups are shown. 
A

B
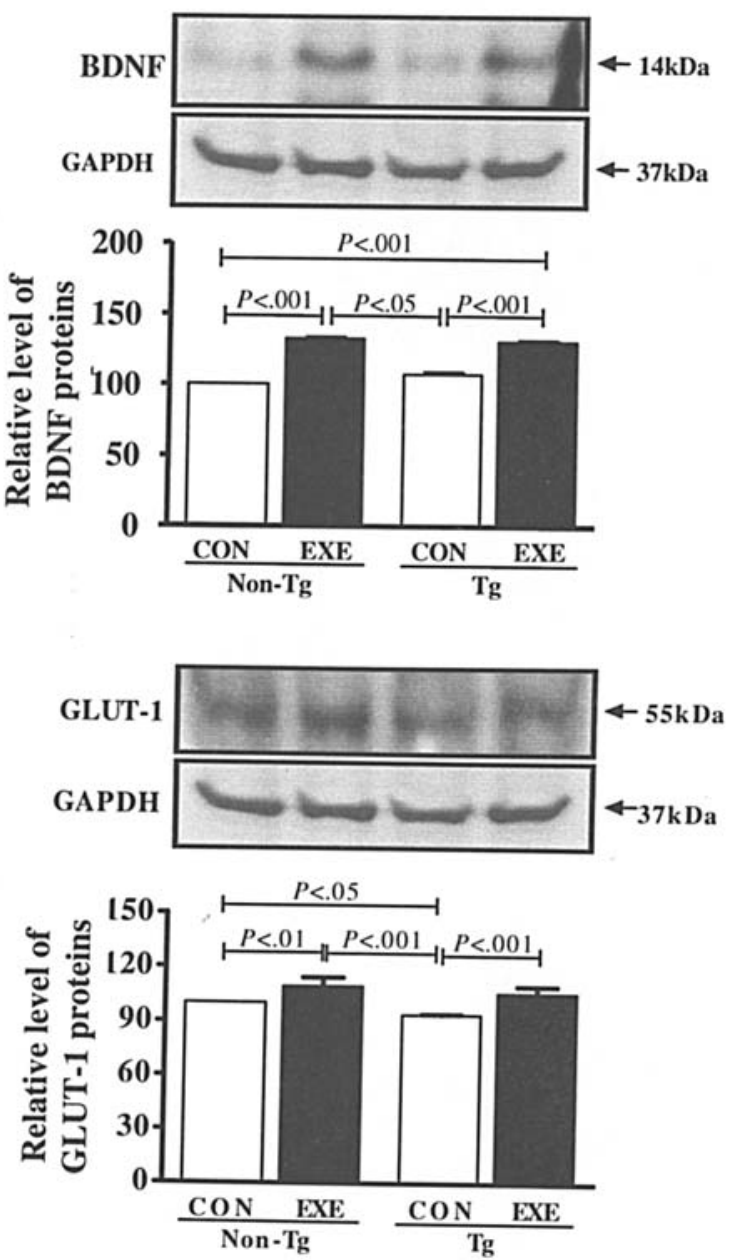

Figure 4. Effects of exercise training on BDNF protein and GLUT-1 protein in the brain of APPsw Tg mice. The levels of BNDF (A) and GLUT-1 (B) protein in the brain were analyzed by Western blot analysis. Briefly, the brain extracts were transferred to membranes and then incubated with antibodies for BDNF, GLUT-1 and GAPDH. The specific activity was then detected with a Chemiluminescence Reagent Plus kit (ECL, Pharmacia). Five mice from the non-Tg and the Tg group were assayed in triplicate. The values shown are the mean $\pm \mathrm{SD}$.

lower in mice that were subjected to exercise for 16 weeks, although the rate at which these levels decreased differed between groups (Fig. 2A). Taken together, these results suggest that exercise training leads to a reduction in the levels of $\mathrm{A} ß-42$ in the brain, possibly by regulating the functional processes of the amyloid precursor protein, and increasing the degradation and clearance of $A ß$.

Improvement of behavioral function by exercise training. The effects of exercise training on the behavioral dysfunction of $\mathrm{AD}$ phenotypes were evaluated by observing the escape distances, swimming speed, escape latencies and swimming patterns of all mice in the SED and EXE groups using water maze tests. In addition, on the 6th day following the 5-day training period, the mice were subjected to three proving trials in which they swam in the pool for $60 \mathrm{sec}$ with the platform removed. In the SED group, NSE/APPsw Tg mice swam for a longer distance and higher latency than mice in the non-Tg group, although there was no difference in the velocity at which the mice swam. After exercise training, the escape distance and latency were significantly decreased in the NSE/APPsw Tg mice (Fig. 3A-a and -c). Although the escape velocity was increased in the EXE groups, this did not affect the results of the escape distance and escape latency tests (Fig. 3A-b). Taken together, these observations suggest that exercise training contributes to the improvement of the behavioral dysfunction of AD in the brains of NSE/APP Tg mice.

Increase of BDNF and GLUT-1 protein level by exercise training. BDNF is one of the principal growth factors involved in mediation of the effects of exercise training on the brain. BDNF has also been shown to exert beneficial effects on synaptic plasticity and may facilitate learning and memory. However, it has been reported that AD may be caused or exacerbated by low levels of BDNF in the basal forebrain (11). Therefore, to determine whether exercise training had any effect on the synaptic plasticity of the brain of NSE/APPsw Tg mice, the expression level of BDNF was evaluated by Western blot analysis, which revealed that the BDNF protein levels in the brains of mice in the EXE groups were much higher than those in the SED groups (Fig. 4A). However, no difference was observed between the Non-Tg and Tg groups. Furthermore, although GLUT-1 is selectively expressed at high levels in the capillary endothelium of the brain and is responsible for the transfer of glucose across the blood brain barrier (32), the amount of GLUT-1 is decreased in the hippocampus and cerebral cortex of AD patients $(33,34)$. Taken together, these findings indicate that the reduction of GLUT-1 reflects the decrease of glucose metabolism and possibly a hypometabolic state. Therefore, we evaluated the GLUT-1 protein levels to determine whether they were increased within the brains of 13 month-old transgenic mice by performing exercise training similar to that of $\mathrm{AD}$ patients. Western blot analysis revealed that the GLUT-1 levels in the brains of mice in the EXE groups were much higher than those of mice in the SED groups (Fig. 4B). These results indicate that the 16-week exercise training affects the synaptic plasticity and glucose metabolism by regulating the BDNF and GLUT-1 levels. However, a similar pattern was detected in the Non-Tg and $\mathrm{Tg}$ mice.

Down-regulation of cytochrome c, caspase-9, caspase-3, Bax protein and up-regulation of the $\mathrm{Bcl}-2$ protein in response to exercise training. Mutations in the gene encoding APP have been shown to cause $\mathrm{AD}$ and lead to the production of $\mathrm{A} B$. The produced $A \beta$ may drive cells into apoptosis and activate the cell death signal pathway. Therefore, $A ß$-induced neuronal death is believed to be caused by caspase and Bcl-2 families. Among the caspase family, caspase- 3 is involved in APP processing, which is consistent with the elevation of $A B$ formation that is observed in the neurons of AD patients (35). Therefore, in this study, exercise training was evaluated to determine whether it was able to prevent or ameliorate cell death in the brains of 13 month-old transgenic mice, as found in AD patients. The Western blot analysis indicated that exercise training had a significant effect on the expression of the pro-apoptotic proteins, caspase- 9 and -3 , as well as on 
A

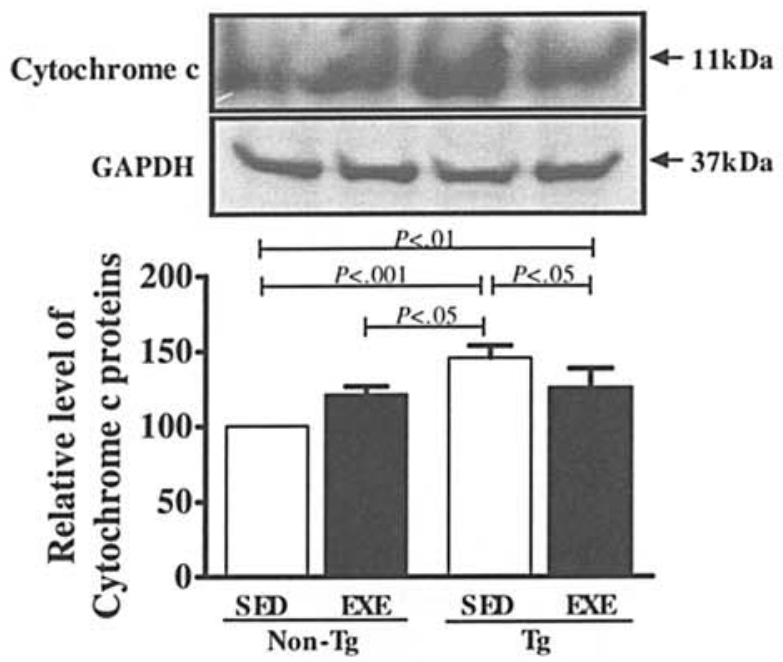

B
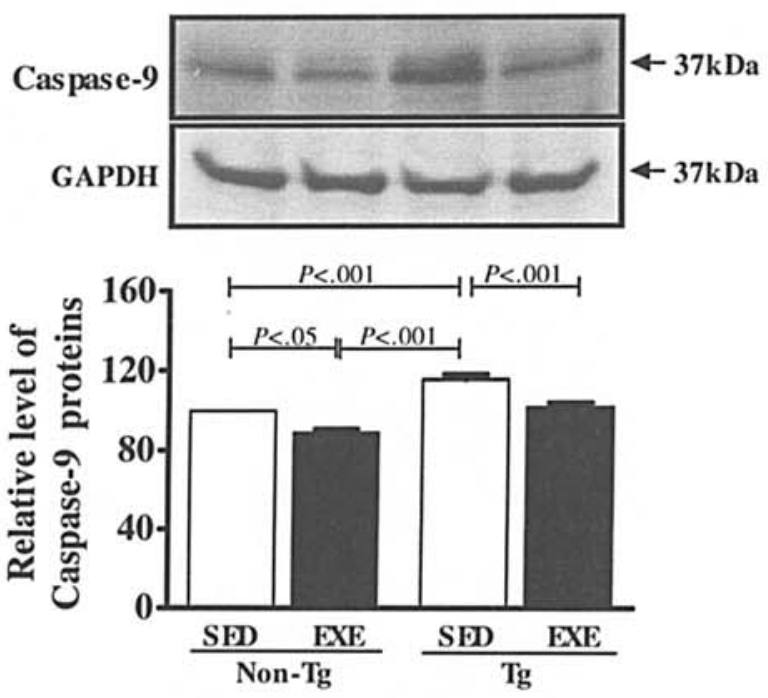

C
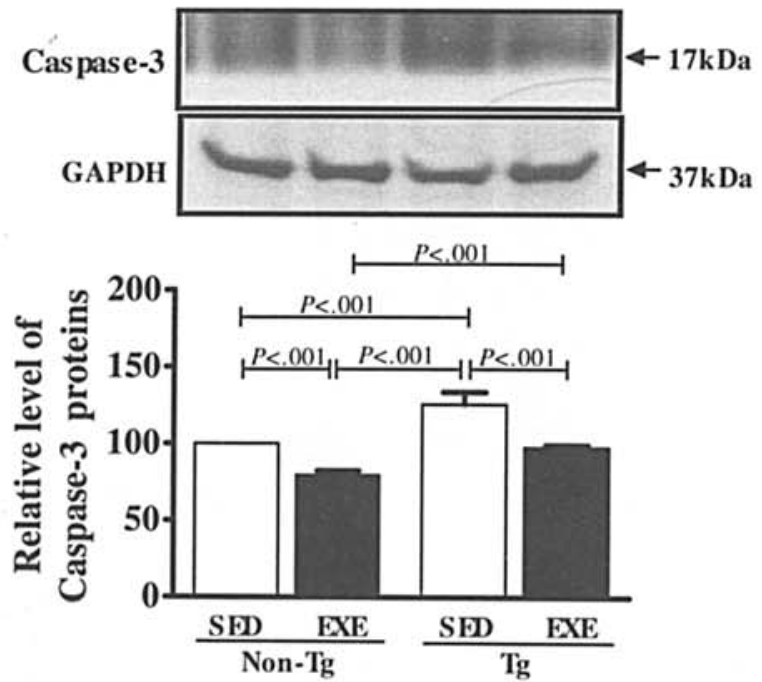

Figure 5. Effect of exercise training on pro-apoptotic proteins (cytochrome c, caspase-9 and -3) in the brain of APPsw Tg mice. Levels of cytochrome c (A), caspase-9 (B) and -3 (C) proteins in the brain were analyzed by Western blot analysis. Briefly, the brain extracts were transferred to membranes and then incubated with antibodies for cytochrome c, caspase-9 and -3 and GAPDH. The specific activity was then detected using a Chemiluminescence Reagent Plus kit. Five mice from the Non-Tg and Tg groups were assayed in triplicate by Western blot analysis. The values shown are the mean \pm SD.
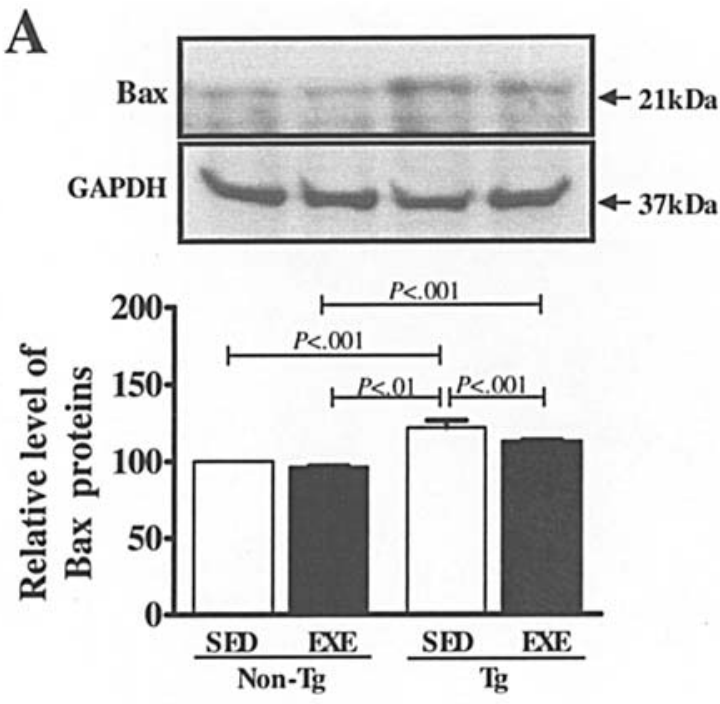

B
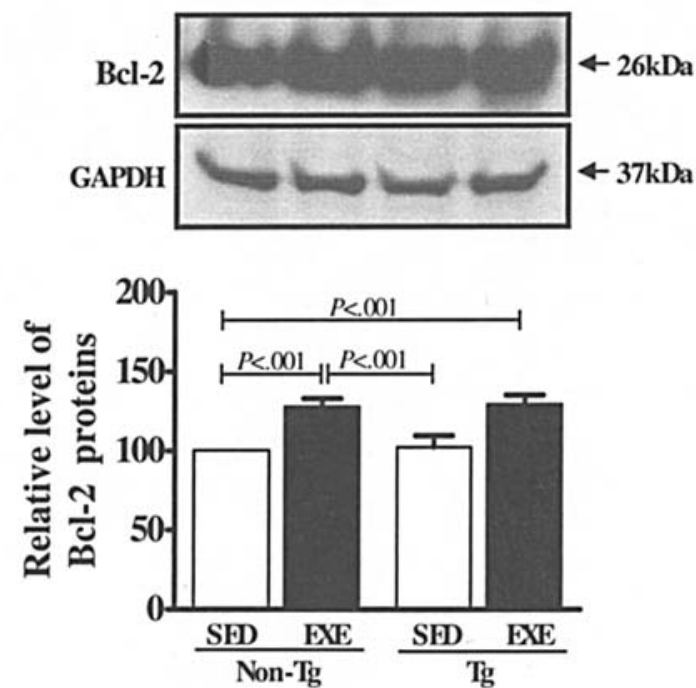

Figure 6. Effect of exercise training on Bax and Bcl-2 protein in the brain of APPsw transgenic mice. The levels of Bax (A) and Bcl-2 (B) protein in the brain were analyzed by Western blot analysis. Briefly, the brain extracts were transferred to membranes and then incubated with antibodies for Bax, Bcl-2 and GAPDH. The specific activity was then detected using a Chemiluminescence Reagent Plus kit. Five mice from the non-Tg and $\mathrm{Tg}$ groups were assayed in triplicate by Western blot analysis. The values shown are the mean $\pm \mathrm{SD}$.

cytochrome c and Bax-initiating apoptosis, and the antiapoptotic protein, Bcl-2, in the brains of Non- $\mathrm{Tg}$ and $\mathrm{Tg}$ mice. Although the Tg mice in the SED group were initially found to have a higher level of pro-apoptotic proteins than the Non-Tg mice, the cytochrome c levels were significantly decreased in the $\mathrm{Tg}$ mice following exercise training (Fig. 5A). However, the caspase- 9 and -3 protein were expressed at lower levels in mice in the EXE group than in the SED group (Fig. 5B and C). Furthermore, the expression level of Bax protein was only reduced in the EXE group of Tg mice, and did not change in the Non-Tg mice (Fig. 6A). Finally, the Bcl-2 protein level was simultaneously increased in the brains of Non-Tg and $\mathrm{Tg}$ mice following exercise training (Fig. 6A and $\mathrm{B})$. Taken together, these results suggest that exercise training attenuates the apoptosis of neuronal cells during 
A
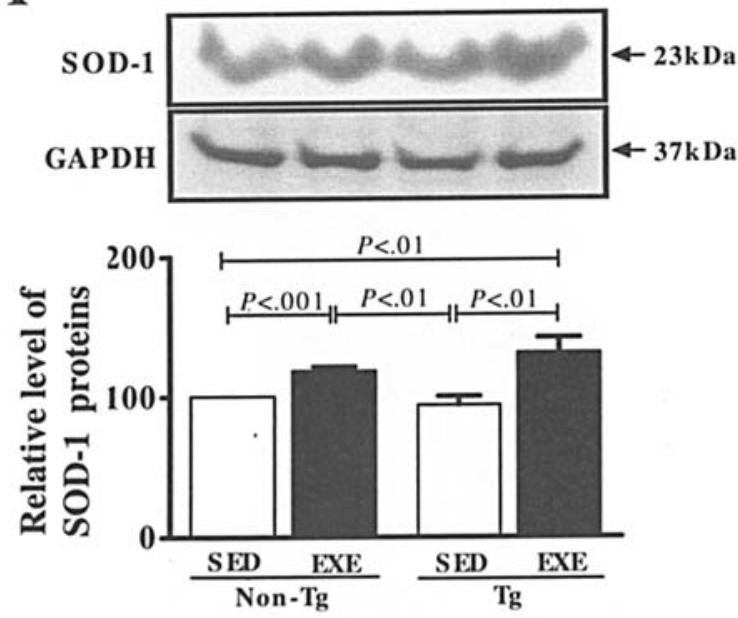

B
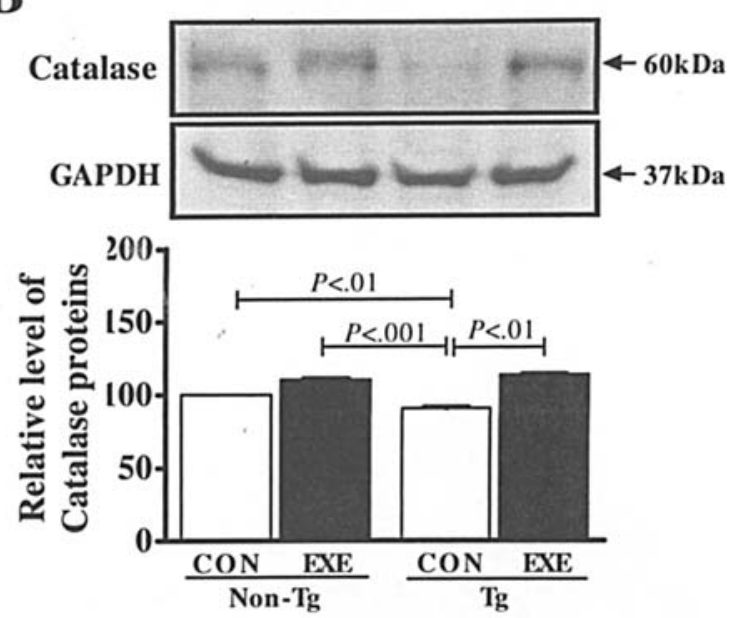

Figure 7. Effect of exercise training on SOD-1 and catalase protein in the brain of APPsw transgenic mice. The levels of SOD-1 (A) and catalase (B) protein in the brain were analyzed by Western blot analysis. Briefly, the brain extracts were transferred to membranes and then incubated with antibodies for SOD-1, catalase and GAPDH. The specific activity was then detected using a Chemiluminescence Reagent Plus kit. Five mice from the non- $\mathrm{Tg}$ and $\mathrm{Tg}$ groups were assayed in triplicate by Western blot analysis. The values shown are the mean \pm SD

AD pathogenesis by regulating the expression level of the apoptosis-related proteins.

Activation of SOD-1 and catalase protein by exercise training. It has been reported that down-regulation of the efficiency of SOD and catalase enzymes may have significant deleterious effects on cell viability (36). Notably, the SOD and catalase activities of $\mathrm{AD}$ patients appear to be very low when compared with non-AD patients. Therefore, exercise training was conducted to determine whether SOD and catalase expression were increased within the brains of the transgenic mice, as found in $\mathrm{AD}$ patients. In the SED group, the $\mathrm{Tg}$ mice were found to have slightly lower levels of SOD-1 and catalase protein than the Non-Tg mice. Following the training exercise, these protein levels were significantly increased in the two groups, although the ratio of the difference between the Non- Tg and Tg groups also increased (Fig. 7A and B). The findings obtained in this study indicate that exercise training can induce a significant increase in the antioxidant capacity of the brains of AD transgenic mice.

Up-regulation of heat-shock protein-70 and glucose-regulated protein-78 by exercise training. HSP-70 is a highly conserved protein that protects neuron cells against excitotoxic and oxidative injury $(37,38)$. This protection is partially related to the inhibition of apoptosis (39). In addition, GRP-78 binding to APP has been shown to decrease Aß1-40 and Aß1-42 secretion (40). However, although the functions of HSP-70 and GRP-78 in AD neuropathology have been suggested, the expression patterns of the individual molecular chaperones in AD affected brain regions are poorly understood. More importantly, the results of this study provide an explanation for the mechanism by which exercise training can affect cell protection in the brains of $\mathrm{Tg}$ mice, as found in $\mathrm{AD}$ patients. Therefore, we investigated the HSP-70 and GRP-78 protein levels to determine whether they increased within the brains of $\mathrm{Tg}$ mice in response to exercise training, as found in $\mathrm{AD}$ patients. The levels of HSP-70 were much lower in Tg mice in the SED group than in the Non-Tg mice. However, the GRP-78 levels were slightly higher in the Tg mice than in the Non-Tg mice. Following 16 weeks of exercise training, the HSP-70 and GRP-78 protein levels were significantly increased in the Non-Tg and Tg mice (Fig. 8A and B). These results suggest that exercise training contributes to the mechanism by which the brain is protected by inducing the production of HSP-70 and GRP-78.

Changes in metabolic parameters. The complex association between cholesterol, glucose, insulin, and AD has been investigated by previous studies (15). High levels of total cholesterol (TC) and insulin affect the B-amyloid synthesis and amyloid precursor protein (APP) metabolism because cholesterol levels modulate the $\gamma$-secretase activity and $\beta$-amyloid synthesis (17). Furthermore, there is growing evidence that impairments in insulin signaling are partly responsible for the cognitive decline in $\mathrm{AD}$, and glucose metabolic abnormalities such as hyperglycemia and hyperinsulinemia have been proposed as contributing or associated factors. Therefore, exercise training was evaluated to determine whether it affected several metabolic parameters such as TC, high density lipoprotein (HDL-C), glucose and insulin levels. Prior to the exercise training, Tg mice had a higher concentration of TC, glucose and insulin than Non-Tg mice, while they had a lower concentration of HDL-C. After 16 weeks of exercise training, the concentrations of TC and glucose significantly decreased in Non- Tg and Tg mice when compared to the SED Non-Tg and $\mathrm{Tg}$ mice (Fig. 9A and C), whereas the levels of HDL-C significantly increased (Fig. 9B). Moreover, the concentration of insulin decreased in the EXE groups when compared with the SED groups (Fig. 9D). Taken together, these results suggest that exercise training is a feasible and effective method for reducing TC, glucose, and insulin levels and elevating HDL-C levels in patients with AD.

\section{Discussion}

$\mathrm{AD}$ is a multifactorial neurodegenerative disease characterized by the presence of $A ß$ peptide containing plaques and 
A
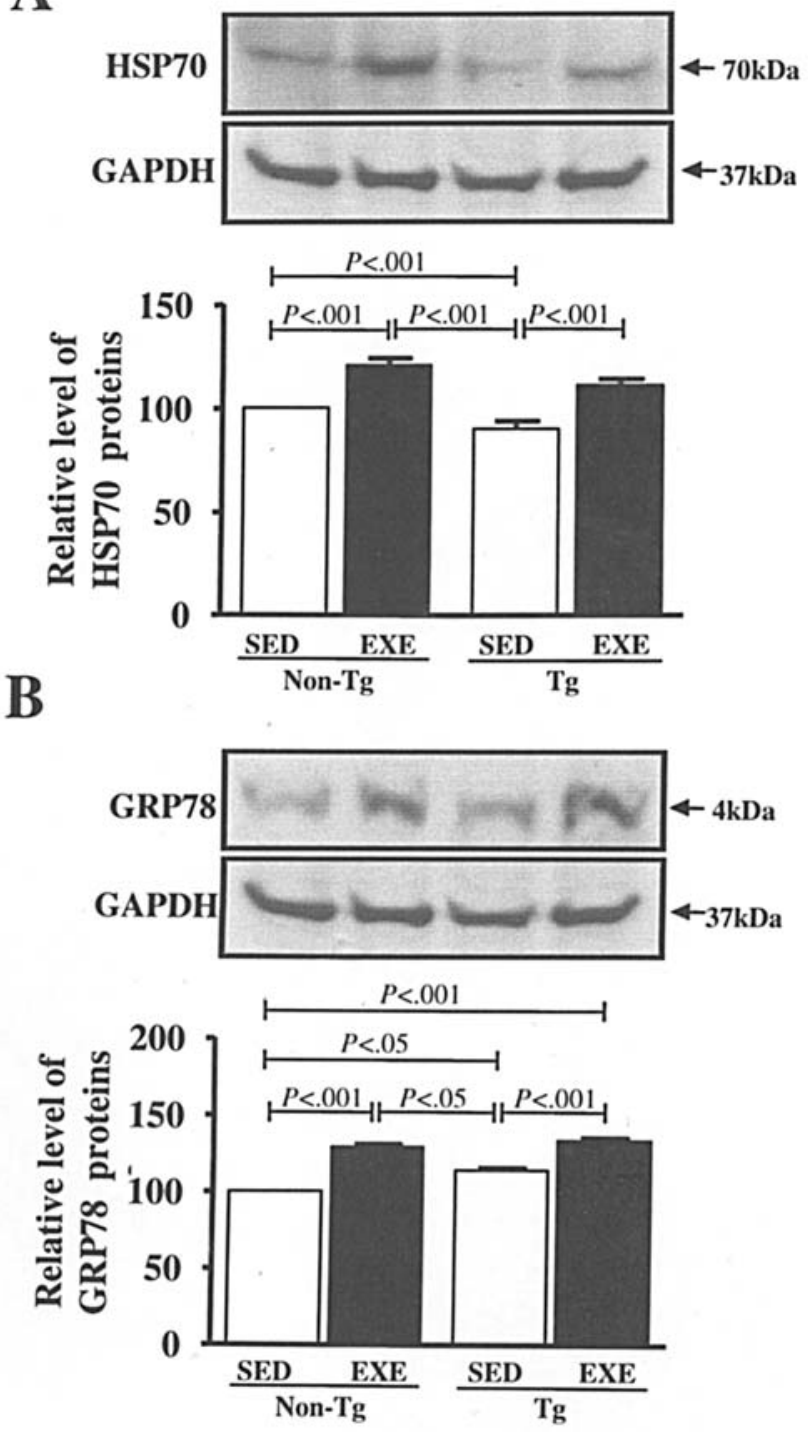

Figure 8. Effect of exercise training on HSP-70 and GRP-78 in the brain of APPsw Tg mice. Levels of HSP-70 (A) and GRP-78 (B) protein were analyzed by Western blot analysis. Briefly, the brain extracts were transferred to membranes and then incubated with antibodies for HSP-70, GRP-78 and GAPDH. The specific activity was then detected using a Chemiluminescence Reagent Plus kit. Five mice from the non- $\mathrm{Tg}$ and $\mathrm{Tg}$ groups were assayed in triplicate by Western blot analysis. The values shown are the mean \pm SD

neurofibrillary tangles that are major contributors to the neurodegenerative processes. However, there are many socially and practically prohibitive issues in recruiting individuals with $\mathrm{AD}$ for the purpose of a scientific study. Therefore, we used NSE/APPsw Tg mice models that exhibit behavioral deficits and elevated levels of Aß-42 in the brain to better understand the fundamental mechanisms involved in the pathological changes underlying $\operatorname{AD}(29,41,42)$ and evaluate the protective effects of exercise training on molecular pathogenic phenotypes involved in $\mathrm{AD}$. The results of this study revealed that $A B-42$ protein levels were significantly decreased in the EXE groups after 16 weeks when compared with the SED groups, which is in agreement with the results of previous studies $(20,21,43)$. Therefore, these findings suggest that exercise training can be used to prevent accumulation of the amyloid precursor protein because it induces increased degradation and clearance of $\mathrm{A} ß(21,44)$.

One of the most important findings of the present study is that exercise training had significant effects on the elevation of BDNF protein levels, as well as on the improvement of behavioral dysfunctions in NSE/APPsw Tg mice. Other studies have reported that exercise is a simple behavioral intervention that is sufficient to inhibit the normal progress of AD neuropathology $(21,45,46)$. This finding was confirmed by the results of the present study, which demonstrate that it is possible to elicit positive cognitive changes in $\mathrm{Tg}$ mice by subjecting them to exercise training. The underlying molecular mechanisms responsible for this phenomenon indicate that exercise training can improve behavioral deficits, possibly through a reduction of the Aß-42 peptide load paralleled by an increased production of neurotrophic factors (NGF, BDNF and IGF-1), which are important for neuronal survival, neuronal proliferation and synaptic plasticity $(47,48)$.

Furthermore, $A ß$ deposition is related to decreased GLUT-1 levels in the brains of AD transgenic mice, which is in agreement with the results of this study $(13,34,49,50)$. Therefore, decreased GLUT-1 protein levels may be caused by a reduced capillary density or as a result of decreased GLUT-1 level/ capillary density. Moreover, decreased GLUT-1 protein levels affect the cognitive deficit associated with AD. Conversely, exercise training decreases brain cell damage caused by oxygen and glucose deprivation while increasing the level of glutamate receptors that stimulate the glucose uptake that is mediated by the activation of GLUT-1 $(45,51)$. However, the exact mechanism by which exercise training affects the GLUT-1 protein levels in AD is still unknown. Therefore, exercise training was evaluated to determine whether it could increase GLUT-1 protein levels in the brains of 13 month-old $\mathrm{AD}$ transgenic mice. The results of this study revealed an increase in the GLUT-1 protein levels in EXE Non-Tg and Tg mice, which suggests that those changes were associated with a reduction in $A \beta-42$ levels and clinical reductions in metabolic parameters (TC, glucose and insulin). Taken together, these findings indicate that exercise training likely involves the promotion of GLUT-1 synthesis or a reduction of GLUT-1 degradation. Therefore, the increases in GLUT-1 protein levels induced by exercise training may occur due to reductions in Aß-42 protein levels and decreases in the GLUT-1 level/ capillary density with concomitant reductions of TC, glucose and insulin levels in APPsw transgenic mice.

Inappropriate apoptosis has been implicated in many human diseases, including AD. Notably, AD patients exhibit high levels of AB-42 deposition and the apoptosis of neuronal cells mediated by apoptotic-related pathways or apoptosis itself. In contrast, exercise training reduces amyloid- $\beta$ plaques and improves spatial learning, memory, synaptic plasticity, and neurogenesis in AD transgenic mice $(20,52)$. However, the exact mechanisms that regulate the effects of exercise training on apoptosis in AD are unknown. Therefore, in this study, exercise training was evaluated to determine whether it was able to prevent or ameliorate cell death in the brains of $\mathrm{Tg}$ mice, as found in $\mathrm{AD}$ patients. Our study is the first to demonstrate that cytosolic cytochrome c, caspase-9, caspase-3 and Bax protein levels were significantly reduced in the brains of EXE Tg mice when compared with SED Tg mice. 
A

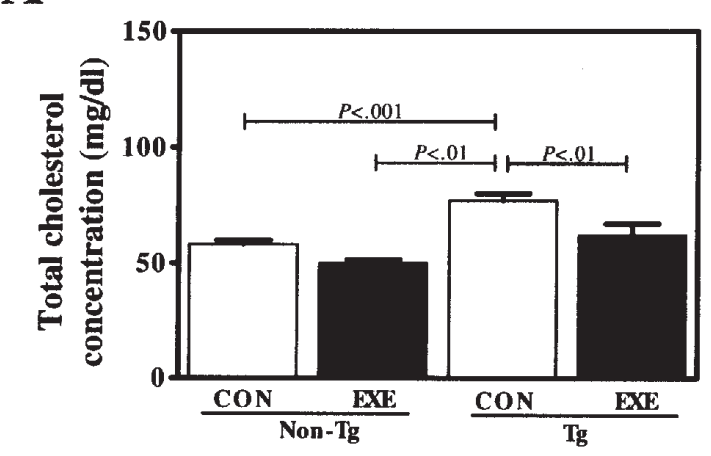

C

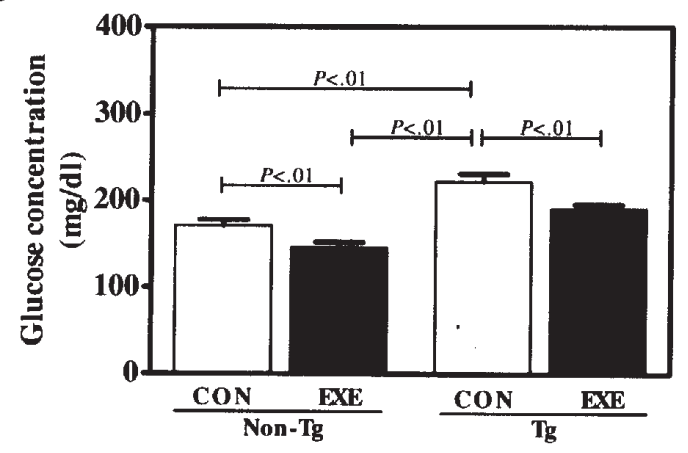

B

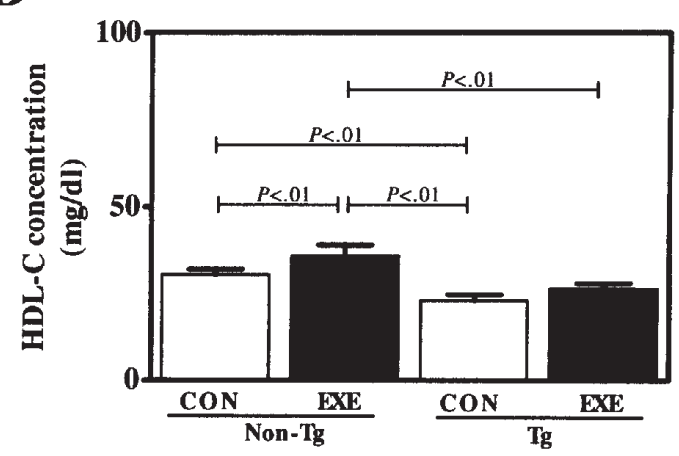

D

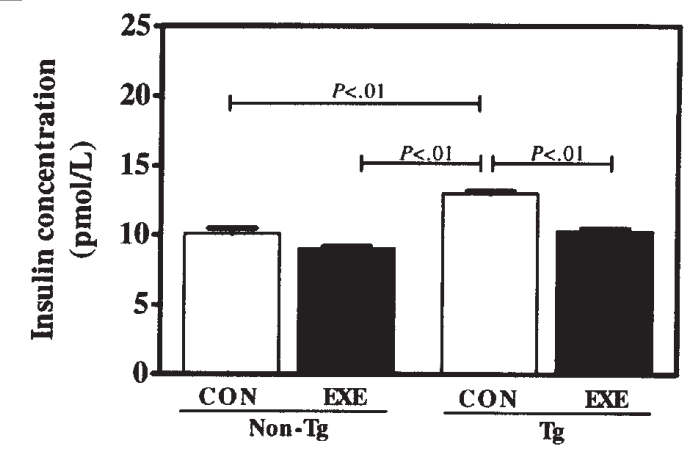

Figure 9. Effects of the serum biochemical profile as it relates to glucose metabolism in the EXE and SED groups. Blood was collected from the abdominal vein of the mice, and the serum level of TC (A), HDL-C (B) and glucose (C) was analyzed using a serum biochemical analyzer. In addition, the insulin concentrations (D) were measured using the ultra-sensitive assay procedure and reagents in the Insulin ELISA kit. Five mice were assayed in triplicate. The values shown are the mean $\pm \mathrm{SD}$.

Therefore, the reduction of pro-apoptotic proteins, including cytochrome $\mathrm{c}$ and Bax, by exercise training in APPsw Tg mice may be mechanistically linked to a reduction in the $A \beta-42$ protein level, possibly via the inhibition of apoptotic-related caspase pathways (8). Moreover, the important observation in this study was that the Bcl-2 protein level is significantly elevated in the brains of EXE Tg mice when compared with SED Tg mice. This is of note because a previous study indicated that exercise training can lead to neuronal resistance against apoptotic and oxidative injury (53), possibly through the reduction of $\mathrm{A} \beta$-induced apoptosis. Therefore, these results suggest that regular exercise training attenuates the apoptosis of neuronal cells involved in the pathogenesis of AD by increasing the degradation or clearance of $A ß$. This conclusion conforms to the results of several previous studies $(54,55)$.

Reduction of the antioxidant capacity is associated with a variety of neurological disorders, including Parkinson's disease (PD) and AD (36). In contrast, regular exercise training significantly reduced the risks of dementia and $\mathrm{AD}$, and improved the antioxidant capacities, which resulted in the prevention of apoptosis and cell loss (56). The results of the present study revealed significantly increased SOD-1 and catalase protein levels in the brains of EXE Tg mice when compared with SED Tg mice. Those changes were associated with a reduction of apoptotic proteins (cytochrome c, caspase-9, caspase-3 and Bax) and an elevation of HSP-70 and BDNF proteins, which were induced in the brain by regular exercise training and subsequently mediated by a clinical reduction of Aß-42 peptides in APPsw Tg mice. Taken together, these findings indicate that exercise training has a better ability to induce antioxidant enzymes to cope with the superoxides formed in $\mathrm{AD} \mathrm{Tg}$ mice, which is in agreement with the results of several previous studies $(57,58)$.

HSPs are ubiquitously expressed intracellular proteins that protect proteins and DNA from stress-induced damage (59). Among the HSPs, HSP-70 has been reported to inhibit the self-assembly of poly-glutamine proteins into amyloid-like fibrils (60). GRP-78 also binds to APP and induces a decrease in the secretion of Aß1-40 and Aß1-42 (40). However, it is not yet known whether HSP-70 and GRP-78 increase within the brains of AD-transgenic mice during exercise training. Therefore, we tested for the presence of these proteins during exercise training in this study. We found that the protein levels of HSP-70 and GRP-78 increased in the brains of EXE Non-Tg and Tg mice when compared with SED Non-Tg and Tg mice. These findings suggest that HSP-70 and GRP-78 proteins can protect neurons against excitotoxic and oxidative injury $(37,61)$, which suggests that regular exercise training contributes to a neuroprotective effect of the brains of ADtransgenic mice. Moreover, increased levels of HSP-70 and GRP-78 proteins following exercise training may benefit the brain, making it more resistant to stress-induced cell damage. These results confirmed the results reported by several previously conducted studies that used the novel AD model expressing human APPsw gene under the control of the NSE promoter $(40,62)$.

Finally, in this study, SED Non-Tg and Tg mice were found to have higher total cholesterol, insulin and glucose levels in the serum than their exercise-trained counterparts. These results validate the findings of previous studies $(16,17)$, 
and indicate that the elevated circulating metabolic parameters may be mechanistically linked to elevation of the Aß-42 levels, possibly via the inhibition of glucose utilization, glucose transport, or insulin signaling $(63,64)$. The results of this study also confirm the results of other studies (20) that showed that marked reductions in metabolic parameters (TC, glucose and insulin) can be elicited by exercise training in AD $\mathrm{Tg}$ mice. More importantly, exercise training resulted in a further decrease of circulating glucose, insulin and cholesterol levels in this study. Taken together, these results suggest that regular exercise training eases the impairment of glucose metabolism, insulin resistance and the reduction of cholesterol production in the brains of APPsw Tg mice by regulating GLUT-1 protein expression and the concentration of glucose, insulin and $A ß$ peptide. In conclusion, based on the evidence presented in this study, regular exercise training is a practical therapeutic management strategy for human subjects with AD.

The aforementioned results showed that exercise training can serve as a therapeutic method for the prevention of $A ß-42$ peptides and neuronal cell death by ameliorating the pathogenic phenotypes of $\mathrm{AD}$. However, in order to apply these methods to humans further investigation of the exercise conditions is required.

\section{Acknowledgements}

We thank the animal technicians, Hee-S Bae, Young-T Shin, Yoo-J Hwang, Young-H Rho and Ji-Y Kim for directing the animal facility at the Korea National Sport University. This investigation was supported by grants to Dr Joon Y. Cho from the Korea Institute of Sport Science, Seoul Olympic Promotion Foundation (01-PJ1-963-20500-0129).

\section{References}

1. Ray WJ, Ashall F and Goate AM: Molecular pathogenesis of sporadic and familial forms of Alzheimer's disease. Mol Med Today 4: 151-157, 1998.

2. Cotman CW and Anderson AJ: A potential role for apoptosis in neurodegeneration and Alzheimer's disease. Mol Neurobiol 10: 19-45, 1995.

3. Behl C, Davis JB, Lesley R and Schubert D: Hydrogen peroxide mediates amyloid beta protein toxicity. Cell 77: 17-27, 1994.

4. Montine TJ, Markesbery WR, Zackert W, Sanchez SC, Roberts LJ Jr and Morrow JD: The magnitude of brain lipid peroxidation correlates with the extent of degeneration but not with density of neuritic plaques or neurofibrillary tangles or with APOE genotype in Alzheimer's disease patients. Am J Pathol 155: 863-868, 1999.

5. McGrath LT, McGleenon BM, Brennan S, McColl D, McILroy S and Passmore AP: Increased oxidative stress in Alzheimer's disease as assessed with 4-hydroxynonenal but not malondialdehyde. QJM 94: 485-490, 2001.

6. Monji A, Utsumi H, Ueda T, Imoto T, Yoshida I, Hashioka S, Tashiro $\mathrm{K}$ and Tashiro N: The relationship between the aggregational state of the amyloid-beta peptides and free radical generation by the peptides. J Neurochem 77: 1425-1432, 2001

7. Boland B and Campbell V: Beta-amyloid (1-40)-induced apoptosis of cultured cortical neurones involves calpain-mediated cleavage of poly-ADP-ribose polymerase. Neurobiol Aging 24: 179-186, 2003.

8. Lesné S, Gabriel C, Nelson DA, White E, Mackenzie ET, Vivien D and Buisson A: Akt-dependent expression of NAIP-1 protects neurons against amyloid-\{beta\} toxicity. J Biol Chem 280: 24941-24947, 2005.

9. Yao M, Nguyen TV and Pike CJ: Beta-amyloid-induced neuronal apoptosis involves c-Jun $\mathrm{N}$-terminal kinase-dependent downregulation of Bcl-w. J Neurosci 25: 1149-1158, 2005.
10. Scott SA, Mufson EJ, Weingartner JA, Skau KA and Crutcher KA: Nerve growth factor in Alzheimer's disease: increased levels throughout the brain coupled with declines in nucleus basalis. J Neurosci 15: 6213-6221, 1995.

11. Fahnestock M, Garzon D, Holsinger RM and Michalski B: Neurotrophic factors and Alzheimer's disease: are we focusing on the wrong molecule? J Neural Transm Suppl 62: 241-252, 2002.

12. Mooradian AD, Chung HC and Shah GN: GLUT-1 expression in the cerebra of patients with Alzheimer's disease. Neurobiol Aging 18: 469-474, 1997.

13. Hooijmans CR, Graven C, Dederen PJ, Tanila H, van Groen T and Kiliaan AJ: Amyloid beta deposition is related to decreased glucose transporter-1 levels and hippocampal atrophy in brains of aged APP/PS1 mice. Brain Res 1181: 93-103, 2007.

14. Yoo BC, Kim SH, Cairns N, Fountoulakis M and Lubec G: Deranged expression of molecular chaperones in brains of patients with Alzheimer's disease. Biochem Biophys Res Commun 280: 249-258, 2001.

15. Nelson TJ and Alkon DL: Insulin and cholesterol pathways in neuronal function, memory and neurodegeneration. Biochem Soc Trans 33: 1033-1036, 2005.

16. Watson GS and Craft S: Modulation of memory by insulin and glucose: neuropsychological observations in Alzheimer's disease. Eur J Pharmacol 490: 97-113, 2004.

17. Cole SL, Grudzien A, Manhart IO, Kelly BL, Oakley H and Vassar R: Statins cause intracellular accumulation of amyloid precursor protein, beta-secretase-cleaved fragments, and amyloid beta-peptide via an isoprenoid-dependent mechanism. J Biol Chem 280: 18755-18770, 2005.

18. Franklin CA and Karkeck J: Weight loss and senile dementia in an institutionalized elderly population. J Am Diet Assoc 89: 790-792, 1989.

19. White H, Pieper C, Schmader K and Fillenbaum G: Weight change in Alzheimer disease. J Am Geriat Soc 44: 265-272, 1996.

20. Cho JY, Hwang DY, Kang TS, Shin DH, Hwang JH, Lim CH, Lee SH, Lim HJ, Min SH, Seo SJ, Song YS, Nam KT, Lee KS, Cho JS and Kim YK: Use of NSE/PS2m-transgenic mice in the study of the protective effect of exercise on Alzheimer's disease. J Sports Sci 21: 943-951, 2003.

21. Adlard PA, Perreau VM, Pop V and Cotman CW: Voluntary exercise decreases amyloid load in a transgenic model of Alzheimer's disease. J Neurosci 5: 217-221, 2005.

22. Stevens J and Killeen M: A randomised controlled trial testing the impact of exercise on cognitive symptoms and disability of residents with dementia. Contemp Nurse 21: 32-40, 2006.

23. Cotman CW, Berchtold NC and Christie LA: Exercise builds brain health: key roles of growth factor cascades and inflammation. Trends Neurosci 30: 464-472, 2007.

24. Ari Z, Kutlu N, Uyanik BS, Taneli F, Buyukyazi G and Tavli T: Serum testosterone, growth hormone, and insulin-like growth factor- 1 levels, mental reaction time, and maximal aerobic exercise in sedentary and long-term physically trained elderly males. Int J Neurosci 114: 623-637, 2004.

25. Colcombe SJ, Kramer AF, Erickson KI, Scalf P, McAuley E, Cohen NJ, Webb A, Jerome GJ, Marquez DX and Elavsky S: Cardiovascular fitness, cortical plasticity, and aging. Proc Natl Acad Sci USA 101: 3316-3321, 2004.

26. McAuley E, Kramer AF and Colcombe SJ: Cardiovascular fitness and neurocognitive function in older adults: a brief review. Brain Behav Immun 18: 214-220, 2004.

27. Cotman CW and Berchtold NC: Exercise: a behavioral intervention to enhance brain health and plasticity. Trends Neurosci 25: 295-301, 2002.

28. Wilson RS, Mendes de Leon CF, Barnes LL, Schneider JA, Bienias JL, Evans DA and Bennett DA: Participation in cognitively stimulating activities and risk of incident Alzheimer disease. JAMA 287: 742-748, 2002.

29. Hwang DY, Cho JS, Lee SH, Chae KR, Lim HJ, Min SH, Seo SJ, Song YS, Song CW, Paik SG, Sheen YY and Kim YK: Aberrant expressions of pathogenic phenotype in Alzheimer's diseased transgenic mice carrying NSE-controlled APPsw. Exp Neurol 186: 20-32, 2004.

30. Hwang DY, Sin JS, Kim MS, Yim SY, Kim YK, Kim CK, Kim BG, Shim SB, Jee SW, Lee SH, Bae CJ, Lee BC, Jang MK, Cho JS and Chae KR: Overexpression of human selenoprotein $\mathrm{M}$ differentially regulates the concentrations of antioxidants and $\mathrm{H}_{2} \mathrm{O}_{2}$, the activity of antioxidant enzymes, and the composition of white blood cells in a transgenic rat. Int J Mol Med 21: 169-179, 2008 . 
31. Morris RGM, Garrud P, Rawlins JNP and O'Keefe J: Place navigation impaired in rats with hippocampal lesions. Nature 297: 681-683, 1982.

32. Choeiri C, Staines W and Messier C: Immunohistochemical localization and quantification of glucose transporters in the mouse brain. Neuroscience 111: 19-34, 2002.

33. Horwood $\mathrm{N}$ and Davies DC: Immunolabelling of hippocampal microvessel glucose transporter protein is reduced in Alzheimer's disease. Virchows Arch 425: 69-72, 1994.

34. Simpson IA, Chundu KR, Davies-Hill T, Honer WG and Davies P: Decreased concentrations of GLUT1 and GLUT3 glucose transporters in the brains of patients with Alzheimer's disease. Ann Neurol 35: 546-551, 1994.

35. Gervais FG, Xu D, Robertson GS, Vaillancourt JP, Zhu Y, Huang J, LeBlanc A, Smith D, Rigby M, Shearman MS, Clarke EE, Zheng H, Van Der Ploeg LH, Ruffolo SC, Thornberry NA, Xanthoudakis S, Zamboni RJ, Roy S and Nicholson DW: Involvement of caspases in proteolytic cleavage of Alzheimer's amyloid-beta precursor protein and amyloidogenic A beta peptide formation. Cell 97: 395-406, 1999.

36. Noor R, Mittal S and Iqbal J: Superoxide dismutase - applications and relevance to human diseases. Med Sci Monit 8: 210-215, 2002.

37. Warrick JM, Chan HY, Gray-Board GL, Chai Y, Paulson HL and Bonini NM: Suppression of polyglutamine-mediated neurodegeneration in Drosophila by the molecular chaperone HSP70. Nat Genet 23: 425-428, 1999.

38. Yu Z, Luo H, Fu W and Mattson MP: The endoplasmic reticulum stress-responsive protein GRP78 protects neurons against excitotoxicity and apoptosis: suppression of oxidative stress and stabilization of calcium homeostasis. Exp Neurol 155: 302-314, 1999.

39. Yenari MA, Liu J, Zheng Z, Vexler ZS, Lee JE and Giffard RG: Antiapoptotic and anti-inflammatory mechanisms of heat-shock protein protection. Ann NY Acad Sci 1053: 74-83, 2005.

40. Yang Y, Turner RS and Gaut JR: The chaperone BiP/GRP78 binds to amyloid precursor protein and decreases Abeta-40 and Abeta-42 secretion. J Biol Chem 273: 25552-25555, 1998.

41. Lim HJ, Lim CJ, Hwang DY, Lee SH, Min SH, Song YS, Seo SJ, Park HK, Sheen YY, Cho JS and Kim YK: Carboxyl-terminus of the amyloid protein precursor and ERß are required for estrogenic effect in activating mitogen-activated protein kinase. Int J Mol Med 13: 691-696, 2004.

42. Jee SW, Cho JS, Kim CK, Hwang DY, Shim SB, Lee SH, Sin JS, Kim YS, Park JH, Lee SH, Choi SY and Kim YK: Analysis of differentially expressed genes in early- and late-stage APPswtransgenic and normal mice using cDNA microarray. Int J Mol Med 19: 461-468, 2007.

43. Wolf SA, Kronenberg G, Lehmann K, Blankenship A, Overall R, Staufenbiel M and Kempermann G: Cognitive and physical activity differently modulate disease progression in the amyloid precursor protein (APP)-23 model of Alzheimer's disease. Biol Psychiatry 60: 1314-1323, 2006.

44. Lazarov O, Robinson J, Tang YP, Hairston IS, Korade-Mirnics Z, Lee VM, Hersh LB, Sapolsky RM, Mirnics K and Sisodia SS: Environmental enrichment reduces Abeta levels and amyloid deposition in transgenic mice. Cell 120: 701-713, 2005.

45. Farmer J, Zhao X, van Praag H, Wodtke K, Gage FH and Christie BR: Effects of voluntary exercise on synaptic plasticity and gene expression in the dentate gyrus of adult male SpragueDawley rats in vivo. Neuroscience 124: 71-79, 2004.

46. Neeper SA, Gómez-Pinilla F, Choi J and Cotman CW: Exercise and brain neurotrophins. Nature 373: 109, 1995.

47. Lu B and Chow A: Neurotrophins and hippocampal synaptic transmission and plasticity. J Neurosci Res 58: 76-87, 1999.
48. Trejo JL, Carro E and Torres-Aleman I: Circulating insulin-like growth factor I mediates exercise-induced increases in the number of new neurons in the adult hippocampus. J Neurosci 21: 1628-1634, 2001

49. Kouznetsova E, Klingner M, Sorger D, Sabri O, Grossmann U, Steinbach J, Scheunemann M and Schliebs R: Developmental and amyloid plaque-related changes in cerebral cortical capillaries in transgenic Tg2576 Alzheimer mice. Int J Dev Neurosci 24: 187-193, 2006.

50. Schultheiss C, Blechert B, Gaertner FC, Drecoll E, Mueller J, Weber GF, Drzezga A and Essler M: In vivo characterization of endothelial cell activation in a transgenic mouse model of Alzheimer's disease. Angiogenesis 9: 59-65, 2006.

51. Cechetti F, Rhod A, Simão F, Santin K, Salbego C, Netto CA and Siqueira IR: Effect of treadmill exercise on cell damage in rat hippocampal slices submitted to oxygen and glucose deprivation. Brain Res 1157: 121-125, 2007.

52. Nichol KE, Parachikova AI and Cotman CW: Three weeks of running wheel exposure improves cognitive performance in the aged Tg2576 mouse. Behav Brain Res 184: 124-132, 2007.

53. Merry DE and Korsmeyer SJ: Bcl-2 gene family in the nervous system. Annu Rev Neurosci 20: 245-267, 1997.

54. Lee MH, Kim H, Kim SS, Lee TH, Lim BV, Chang HK, Jang MH, Shin MC, Shin MS and Kim CJ: Treadmill exercise suppresses ischemia-induced increment in apoptosis and cell proliferation in hippocampal dentate gyrus of gerbils. Life Sci 73: 2455-2465, 2003.

55. Karlnoski R, Wilcock D, Dickey C, Ronan V, Gordon MN, Zhang W, Morgan D and Taglialatela G: Up-regulation of Bcl-2 in APP transgenic mice is associated with neuroprotection. Neurobiol Dis 25: 179-188, 2007.

56. Somani SM, Ravi R and Rybak LP: Effect of exercise training on antioxidant system in brain regions of rat. Pharmacol Biochem Behav 50: 635-639, 1995

57. Mattson MP: Energy intake, meal frequency, and health: a neurobiological perspective. Annu Rev Nutr 25: 237-260, 2005.

58. Mattson MP and Magnus T: Ageing and neuronal vulnerability. Nat Rev Neurosci 7: 278-294, 2006.

59. Asea A, Kraeft SK, Kurt-Jones EA, Stevenson MA, Chen LB, Finberg RW, Koo GC and Calderwood SK: HSP70 stimulates cytokine production through a CD14-dependent pathway, demonstrating its dual role as a chaperone and cytokine. Nat Med 6: 435-442, 2000.

60. Muchowski PJ, Schaffar G, Sittler A, Wanker EE, Hayer-Hartl MK and Hartl FU: Hsp70 and hsp40 chaperones can inhibit selfassembly of polyglutamine proteins into amyloid-like fibrils. Proc Natl Acad Sci USA 97: 7841-7846, 2000.

61. Yoo BC, Seidl R, Cairns N and Lubec G: Heat-shock protein 70 levels in brain of patients with Down syndrome and Alzheimer's disease. J Neural Transm (Suppl) 57: 315-322, 1999.

62. Campisi J, Leem TH, Greenwood BN, Hansen MK, Moraska A, Higgins K, Smith TP and Fleshner M: Habitual physical activity facilitates stress-induced HSP72 induction in brain, peripheral, and immune tissues. Am J Physiol Regul Integr Comp Physiol 284: 520-530, 2003

63. Friedland RP, Jagust WJ, Huesman RH, Koss E, Knittel B, Mathis CA, Ober BA, Mazoyer BM and Budinger TF: Regional cerebral glucose transport and utilization in Alzheimer's disease. Neurology 39: 1427-1434, 1989.

64. de la Monte SM and Wands JR: Review of insulin and insulinlike growth factor expression, signaling, and malfunction in the central nervous system: relevance to Alzheimer's disease. J Alzheimers Dis 7: 45-61, 2005. 